\title{
POSSIBILITIES OF SONOELASTOGRAPHY IN THE EVALUATION OF THE LOWER THIRD OF FACE SOFT TISSUES CHANGES DETERMINING THE MOST EFFECTIVE METHOD OF CORRECTION: A PILOT STUDY USING SONOELASTOGRAPHY
}

\author{
Yu.A. Stepanova, D.A. Kiseleva*, N.O. Sultanova
}

A.V. Vishnevsky National Medical Research Center of Surgery, Moscow, Russian Federation

\begin{abstract}
The article discusses the use of shear wave elastography in assessment of age-related atrophy of muscle tissue in the lower third of face as a preoperative diagnostic option. The aim was to study the possibility of using sonoelastography in the study of changes in elasticity of muscle tissue of the lower third of the face in women as a result of age-related atrophic processes. The research involved 45 women divided into three equal groups by age (20-30, 30-4O and 4O-6o years old). Elasticity of muscle tissue in the area of buccinator muscle was assessed using shear wave elastography. A statistically significant progressive decrease in the elasticity of muscle tissue in the lower third of face, associated with the age-related atrophy, was revealed. We have shown that using sonoelastography it is possible to display atrophic processes in the facial muscle tissue, which can be used in future in preoperative diagnosis and selection of the optimal correction method. It is a promising method for evaluating age-related changes in soft tissues in aesthetic medicine and cosmetology. Further research on the application of this method can contribute to its implementation in everyday practice in this field of medicine.
\end{abstract}

Key words: Ultrasound diagnostics, shear wave elastography, facial aging, muscle elasticity, aesthetic medicine

\section{INTRODUCTION}

The appeal to plastic surgeons, especially for aesthetic operations, is currently growing, which is often associated with a loss of physical attractiveness due to age-related changes. Women aged 35 to $60+$ years are especially interested in improvement of their appearance, since a youthful appearance is often associated with a prosperous lifestyle.

Specialists in aesthetic cosmetology have a large number of methods for improving the appearance of the face and neck - SMAS lifting, rhinoplasty, blepharoplasty, circular facelifts, injections of botulinum toxin, hyaluronic acid, bio revitalization and much more [1]. The choice of procedures usually depends on the problem of the patient, on the qualifications of the plastic surgeon and the availability of specialized equipment. However, the intervention chosen for the patient may not lead to the expected result, even if the operation is performed correctly and the recommendations of the postoperative period are followed. The reason for this may be the lack of preoperative diagnostics. Currently, there are practically no methods for an objective assessment of age-related changes in soft tissues in the lower third of the face, although there is a need for such methods.

The main method for assessing the state of the patient's muscle tissue is a visual assessment by a plastic surgeon. Currently, ultrasound is an important and informative diagnostic method in almost any field of medicine. In recent decades, a method of ultrasound diagnostics such as sonoelastography has been used to study soft tissues and their structural changes [2]. Using that, it is possible to quantitatively and qualitatively assess the elasticity of soft tissues, supplemented, if necessary, with information obtained using traditional methods: studies in B-mode and duplex scanning of local blood flow.

The use of sonoelastography in the assessment of facial soft tissues has been identified in three studies to date. L. Paluch et al. [3] in 2019 used SWE in their study to objectively assess changes in facial tissues after using such a non-invasive rejuvenation technique as high-intensity focused ultrasound. Sonoelastography has also been used in an attempt to identify and indicate normal values of skin elasticity in various areas of the face [4]. Also, A.M. Alfuraih et al. [5] used the method of shear wave elastography to study the aging processes of muscle tissue. Based on the data obtained, it was not possible to reveal any connections between the mass of muscle tissue and the results of sonoelastography within the framework of the three groups. At the same time, the authors proved that with age, there is a progressive decrease in the elasticity of muscle tissue and tendons, objectively reflected in the results of ultrasound measurements. Currently, sonoelastography in aesthetic surgery and cosmetology is just beginning to find its application and distribution. For preoperative diagnostics for interventions in the face area, traditional ultrasound is

\footnotetext{
*lushfur@gmail.com
} 
much more often used, for example, to visualize the anatomical location of facial muscles and assess the interposition of the facial layers and vascular branches [6], assess fat atrophy [7]. In Russia, ultrasound was used in blepharoplasty to assess the condition of the eyelids to achieve the best result [8].

\section{MATERIALS AND METHODS}

The study involved 45 women. All subjects were divided into three age groups of 15 people each: 20-30 years old (group 1), 30-40 years old (group 2) and 4060 years old (group 3). The division into the indicated groups was necessary to assess the differences in the indicators of muscle tissue elasticity depending on age. It was assumed that the results among subjects within the same age group with a step from the minimum to the maximum value of ten years will differ slightly. In group 3 , the age of the subjects varied from 40 to 60 years, which was explained by the fact that after the age of 40 more women had already had some kind of corrective cosmetic intervention on the face.

For the study, it was important to take into account the data of the anamnesis of the participants. According to the data obtained as a result of the survey, all subjects are healthy. The members have never been exposed to invasive facial treatments. Also, they did not engage in activities contributing to the active use of facial muscles and articulation, which may affect on the elasticity of the muscle tissue of the face regardless of age (such as acting, singing, dubbing, teaching languages).

The study involved only 45 women due to the epidemiological situation (COVID-19) in the country. Our center has been refurbished for treatment with coronavirus infection, which has imposed a halt on recruitment. All of them were volunteers and signed an informed voluntary consent to participate in the study. All participants who took part in our study were of Caucasian origin. Further, it was planned to increase the number of participants and reach diversity, however, due to aforecited circumstances, the expanded study was postponed.

The elasticity of the muscle tissue was measured using an SL 10-2 linear sensor with a possible frequency range of 2-10 $\mathrm{MHz}$. The frequency for research was $7.5 \mathrm{MHz}$. The linear probe is perfect for studying surface structures, because the resulting image is high in clarity and resolution. At the beginning, a B-mode ultrasound study was carried out to verify individual muscle structures and adipose tissue in the examined facial area. The buccal muscle was chosen as the most convenient object for visualization of the facial muscle tissue. Before the study, we also found that there were no significant differences between measurements on the right and left sides of the face, so we used data measured on the left side of the face.

Next, the sonoelastography mode was enabled and a tunable translucent color map of tissue elasticity and B-mode were combined on one screen. The cursor was positioned in the area of interest and the corresponding stiffness indicator was calculated; the unit of measurement was $\mathrm{kPa}$. Measurements were made in the areas of the center and the edges of the buccal muscle, since the density indices in both of the above areas are different. The probe was positioned longitudinally at an angle of $90^{\circ}$ to the muscle. The study was carried out in two positions of the subjects: lying on their back on a couch and standing. A change in position is necessary to determine the difference in the digital readings of the elastogram, since digital differences in measurements in these two positions make it possible to assess the degree of tissue elasticity: the smaller the observed difference in indicators, the more pronounced muscle atrophy in this case. The difference in the indicators measured in these positions can be explained by the influence of the gravitational factor on the muscle tissue.

\section{RESULTS AND DISCUSSION}

Within each group, the average values of elasticity (in $\mathrm{kPa}$ ) of the muscle tissue of the lower third of the face were obtained for each position (standing and lying on the couch) for the abdomen and the edge of the muscle.

In a horizontal position, the effect of gravitational forces on muscle tissue was reflected in the obtained values. All indicators of elasticity, measured in the prone position, are lower in comparison with vertical ones. Within the framework of group 1, the highest indicators of muscle tissue elasticity were obtained. This can be explained by the age of women, since all facial structures have not yet begun to undergo significant age-related changes during the first 30 years. We hypothesized that the observed greater scatter of muscle elasticity values in group 1 may be explained with the young age of the subjects and the different degree of activity of their facial muscles, while the elasticity variability decreases with age.

Table 1. Comparative analysis of mean and standard deviations by age groups

\begin{tabular}{|l|c|c|c|c|c|}
\hline \multirow{2}{*}{$\begin{array}{l}\text { Age } \\
\text { characteristics } \\
\text { of groups }\end{array}$} & $\begin{array}{c}\text { Muscle } \\
\text { center, } \\
\text { vertical }\end{array}$ & $\begin{array}{c}\text { Muscle } \\
\text { edges, } \\
\text { vertical }\end{array}$ & $\begin{array}{c}\text { Muscle } \\
\text { center, } \\
\text { horizontal }\end{array}$ & $\begin{array}{c}\text { Muscle } \\
\text { edges, } \\
\text { horizontal }\end{array}$ \\
\cline { 2 - 6 } & $\mathrm{M} \pm \mathrm{SD}$ & $\mathrm{M} \pm \mathrm{SD}$ & $\mathrm{M} \pm \mathrm{SD}$ & $\mathrm{M} \pm \mathrm{SD}$ \\
\hline \multirow{2}{*}{$\begin{array}{l}\text { Age } \\
\text { group, } \\
\text { years }\end{array}$} & $20-30$ & $10.58 \pm 1.78$ & $13.89 \pm 1.76$ & $9.37 \pm 1.53$ & $12.35 \pm 1.73$ \\
\cline { 2 - 6 } & $30-40$ & $8.09 \pm 1$ & $12.01 \pm 1.1$ & $7.63 \pm 0.88$ & $11.28 \pm 1.13$ \\
\hline $\begin{array}{l}\text { Kruskal- } \\
\text { Wallis H-test }\end{array}$ & $5.8 \pm 1.24$ & $9.12 \pm 1.18$ & $5.44 \pm 1.21$ & $8.59 \pm 1.05$ \\
\hline
\end{tabular}

According to our data, there is a progressive decrease in the values of the average indicators from group 1 to group 3, which reflects the aging process of tissues and a decrease in their elasticity, affecting muscle tissue as well. According to the results obtained in group 3, we found that practically absent differences in elasticity when changing position from vertical to horizontal is observed among older women. This can be explained by age-related changes in muscle tissue, progressive sarcopenia, decreased ability of the muscle to contract, and persistent muscle hypertonicity with aging. 
With a slight change in the muscle elasticity indicator when changing the position of the body it is necessary to make a choice in favor of a full-scale surgical intervention (for example, a facelift), rather than a minimally invasive procedure. In the case of choosing a minimally invasive intervention, with a slight change in the indicator, only a short-term effect will be achieved. For patients this will be associated not only with an increase in the number of procedures and the period of rehabilitation after them, but also with unnecessary material costs.

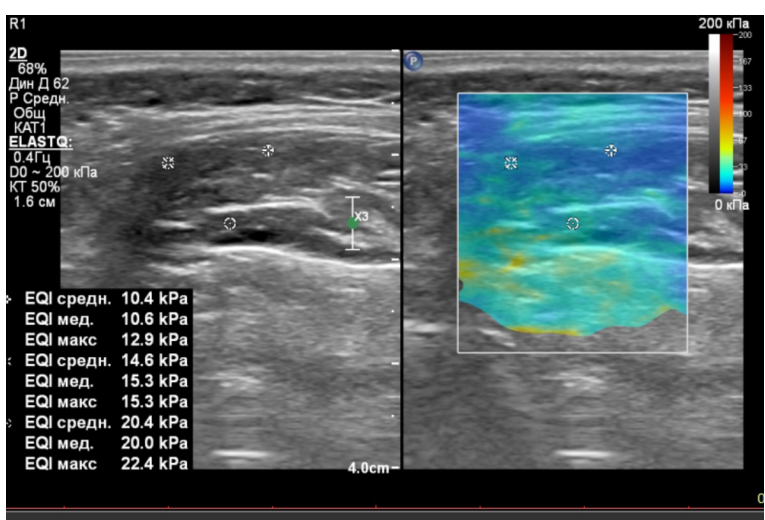

Figure 1. Ultrasound image of the buccal muscle of the patient of group 1 in sonoelastography mode in vertical position

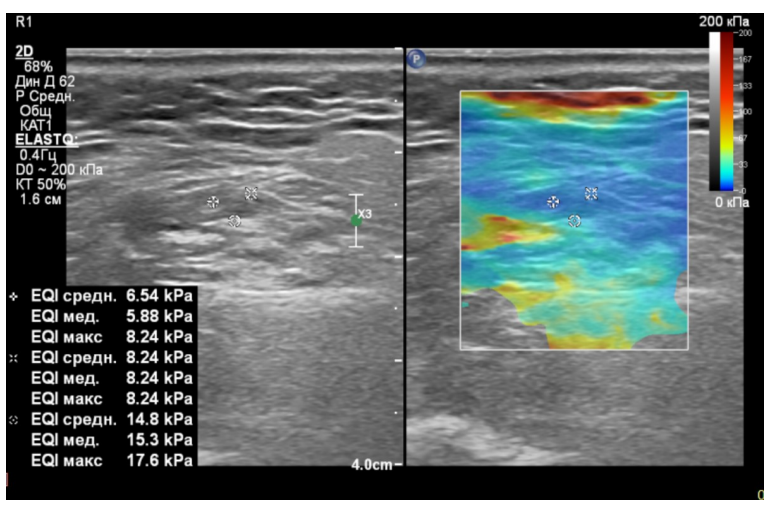

Figure 2. Ultrasound image of the buccal muscle of the patient of group 3 in sonoelastography mode in vertical position

We compared each of the indicators of the three age groups with each other in order to assess the relationship between the measurements on rejection or acceptance of the null hypothesis. The Kruskal-Wallis test for independent samples was used to evaluate the data. The Kruskal-Wallis H-test refers to rank tests and is a multivariate generalization of the Wilcoxon-MannWhitney test for independent samples of three or more. Since our study contains three independent samples three age groups with different parameters - the use of the $\mathrm{H}$-test in the statistical calculations of this study is expedient. The significance level of the criterion in the calculations is 0.05. Based on the results obtained, the null hypothesis is rejected for all distributions of indicators. This means there are significant differences between the age groups 1,2 and 3. We have patented this method of using sonoelastography to assess the elasticity of facial muscles and its importance in choosing correction methods in the Russian Federation [11]-[12].

The results can serve as a basis for future measurements and may be used in planning surgical and cosmetic procedures in the area of the lower third of the face. We hope that this study, along with those already conducted and published earlier, will be able to lead to the introduction of sonoelastography into routine diagnostics before interventions in the field of restorative medicine and cosmetology.

\section{CONCLUSION}

The study of the possibilities of ultrasound assessment of tissues, especially sonoelastography as an instrumental method of pre- and postoperative diagnostics in the field of reconstructive surgery and cosmetology is a promising direction for further research. We hope that in the future the use of sonoelastography in this field of medicine will become more widespread.

\section{REFERENCES}

1. J. Chuang, C. Barnes, B.J.F. Wong, "Overview of Facial Plastic Surgery and Current Developments", Surg. J. $(N-Y)$, vol. 2, no. 1, pp. e17-e28, 2016. https://doi.org/10.1055/s-0036-1572360

2. M.S. Taljanovic et al., "Shear-wave elastography: Basic physics and musculoskeletal applications", RadioGraphics, vol. 37, no. 3, pp. 855-870, 2017 https://doi.org/10.1148/rg.2017160116

3. Y. Sowa, T. Numajiri, K. Nishino, "Ultrasound shearwave elastography for follow-up fat induration after breast reconstruction with an autologous flap", Plastic and Reconstructive Surgery-Global Open, vol. 3, no. 9, article no. e518, 2015. https://doi.org/10.1097/GOX.0000000000000493

4. Y. Sowa, T. Numajiri, S. Itsukage, K. Nishino, "Comparison of Shear-Wave and Strain Ultrasound Elastography for Evaluating Fat Induration after Breast Reconstruction", Plastic and Reconstructive SurgeryGlobal Open, vol. 4, no. 4, article no. e677, 2016. https://doi.org/10.1097/GOX.0000000000000678

5. L. Paluch, M. Ambroziak, P. Pietruski, B. Noszczyk, "Shear Wave Elastography in the Evaluation of Facial Skin Stiffness after Focused Ultrasound Treatment", Dermatologic Surgery, vol. 45, no. 12, pp. 1620-1626, 2019. https://doi.org/10.1097/DSS.0000000000001881

6. M. Ambroziak, B. Noszczyk, P. Pietruski, G. Wieslaw, L. Paluch, "Elastography reference values of facial skin elasticity", Advances in Dermatology and Allergology, vol. 36, no. 5, pp. 626-634, 2019. https://doi.org/10.5114/ada.2018.77502

7. A.M. Alfuraih, A.L. Tan, P. O'Connor, P. Emery, R.J. Wakefield, "The effect of ageing on shear wave elastography muscle stiffness in adults", Aging Clinical and Experimental Research, vol. 31, pp. 1755-1763, 2019.

https://doi.org/10.1007/s40520-019-01139-0

8. S.P. Barlett, I. Wornom, L.A. Whitaker, "Evaluation of facial skeletal aesthetics and surgical planning", Clinical Plastic Surgery, vol. 18, no. 1, pp. 1-9, 1991. PMID: 2015737

9. B. Ascher, P. Katz, "Facial lipoatrophy and the place of ultrasound", Dermatologic Surgery, vol. 32, no. 5, pp. 698-708, 2006. https://doi.org/10.1111/j.1524-4725.2006.32143.x 
Yu.A. Stepanova et al., Sonoelastography in the evaluation of face soft tissues..., RAD Conf. Proc., vol. 5, 2021, 90-93

10. Т.Н. Киселева, М.Г. Катаев, Н.В. Ильина, М.А. Захарова, К.А. Рамазанова, "Метод ультразвукового сканирования в оценке состояния век”, Вестник офтальмологии, т. 130, н. 1, с. 46-51, 2014 .

(T.N. Kiseleva, M.G. Kataev, N.V. Ilyina, M.A. Zakharova, K.A. Ramazanova, "Ultrasound scanning method in assessing the condition of the eyelids", Bulletin of Ophthalmology, vol. 130, no. 1, pp. 46-51, 2014.)

11. Ю.А. Степанова, Д.А. Киселева, Н.О. Султанова, “Способ выбора тактики коррекции возрастных изменений мышечных тканей нижней трети лица по данным эластометрии", Патент на изобретение №2721143, Заявка №2020103904/14(006020), приоритет изобретения от 20.01.2020.

(Yu.A. Stepanova, D.A. Kiseleva, N.O. Sultanova, "Method for choosing tactics for correcting age-related changes in muscle tissues of the lower third of the face according to elastometry data", Patent for invention No. 2721143 (Application No. 2020103904/14 (oo6020), priority of invention dated 20.01.2020)

12. Ю.А. Степанова, Д.А. Киселева, Н.О. Султанова, “Способ определения степени возрастной атрофии мышечной ткани нижней трети лица по данным эластометрии”, Патент на изобретение №2721141, Заявка №2020103905/14(о06021), приоритет изобретения от 20.01.2020 г.

(Yu.A. Stepanova, D.A. Kiseleva, N.O. Sultanova "Method for determining the degree of age-related atrophy of muscle tissue of the lower third of the face according to elastometry data", Patent for invention No. 2721141 (Application No. 2020103905/14 (oo6o21), priority of invention dated 20.01.2020) 